\title{
Gas advection in sediments of a South Carolina salt marsh
}

\author{
James T. Morris \& Gary J. Whiting \\ Department of Biology and Belle W. Baruch Institute, University of South Carolina, Columbia, South Carolina 29208, USA
}

\begin{abstract}
The volume of water removed from marsh sediments by evapotranspiration and drainage during low tide is replaced at least in part by air drawn into the sediment. The volume of gas advected into salt marsh sediments was measured in situ by recording the displacement of air in manometers connected to the sealed headspace of core tubes placed in the sediment. Measurements, made during June and July in short form Spartina alterniflora marshes in South Carolina, indicated that as much as $4.01 \mathrm{~m}^{-2}$ of gas was drawn into the sediment, depending on marsh location and climatic variables. Gas advection rates were equivalent to water losses of 1.5 to $4.0 \%$ of the total sediment water above the water table and corresponded to water table depths that fell to as much as $34 \mathrm{~cm}$ during low tide. Transpiration rates of $S$. alterniflora accounted for about $22 \%$ of the gas volume drawn into the sediment. Analyses of gas bubbles expelled from the sediment during tidal inundation showed that $\mathrm{O}_{2}$ was consumed in excess of $\mathrm{CO}_{2}$ advected. Excess $\mathrm{O}_{2}$ consumption may result because of sulfide oxidation; this possibility is supported by decreasing pore-water $\mathrm{pH}$ during low tide exposure. Alternatively, some $\mathrm{CO}_{2}$ produced in the sediment may remain in the pore water in dissolved form. Considering both advective and diffusive gas fluxes, a total of $56.3 \mathrm{mmol} \mathrm{m}^{-2}$ of $\mathrm{CO}_{2}(4.9$ by advection, 51.4 by diffusion) was evolved from the sediment during low tide compared to a total $\mathrm{O}_{2}$ consumption of $32.9 \mathrm{mmol} \mathrm{m} \mathrm{m}^{-2}$. The mean $\mathrm{O}_{2}$ consumption from gas drawn into the sediment during low tide was 10.9 mmol m $\mathrm{m}^{-2}$. This compares to a mean diffusive $\mathrm{O}_{2}$ consumption by surface sediment of $22.0 \mathrm{mmol} \mathrm{m}^{-2}$ during $10 \mathrm{~h}$ of low tide exposure.
\end{abstract}

\section{INTRODUCTION}

Subsurface water movement and turnover exert a major influence on primary productivity in salt marshes (Mendelssohn \& Seneca 1980, Chalmers 1982, King et al. 1982, DeLaune et al. 1983, Wiegert et al. 1983). Redox potentials generally decrease in waterlogged marsh soils as the turnover of interstitial water decreases (Howes et al. 1981). This results in an oxygen deficiency in Spartina alterniflora roots and anaerobic respiration (Mendelssohn et al. 1981). Oxygen deficiency in roots leads to reduced rates of nitrogen uptake by S. alterniflora (Morris 1984, Morris \& Dacey 1984), which may account for the nitrogenlimited pattern of growth in the short form of $S$. alterniflora that was established experimentally by Sullivan \& Daiber (1974), Valiela \& Teal (1974), Broome et al. (1975), Gallagher (1975), Patrick \& DeLaune (1976) and others.

The movement and turnover of pore-water also has important implications for the biogeochemistry of marsh sediments. Sulfate reduction in anoxic salt marsh sediments is thought to account for most of the decomposition of belowground production (Howarth \& Teal 1979). However, the supply of $\mathrm{SO}_{4}$ from the turnover of sulfides and/or pore-water must be great enough to meet the demands of sulfate-reducing bacteria. Furthermore, there must be a supply of $\mathrm{O}_{2}$ from infiltration of tidal water or other sources great enough to oxidize and prevent the accumulation of the less mobile end-products of sulfate reduction such as pyrite (Howarth 1979, Giblin \& Howarth 1984).

The infiltration of tidal water into the sediments in areas of short Spartina alterniflora is thought to be slight (Hemond et al. 1984). During low tide, evapotranspiration accounted for decreases in water table depth in areas of short S. alterniflora (Dacey \& Howes 1984). It has been argued that water loss from the sediment may be accompanied by sediment compression (Hemond et al. 1984) or air entry (Dacey \& Howes 1984). The consequences of these 2 alternative processes will differ in their effect on sediment chemistry and are important for understanding the mechanisms that regulate primary production in tidal marshes. The 
purpose of our research was to quantify the advection of gas in sediments, investigate some of its consequences, and relate these findings to the overall metabolism of salt marsh sediments.

\section{METHODS}

Site description. Our measurements were made between July and October 1984 in marshes at the Belle W. Baruch Institute, Georgetown, South Carolina. Most measurements were made in an area that was dominated by short form Spartina alterniflora at a site known as Oyster Landing. Other observations were made in a short form $S$. alterniflora area at Bly Creek (Fig. 1). Sediment bulk densities (dry sediment weight/ wet sediment volume) were $1.31 \mathrm{~g} \mathrm{~cm}^{-3}$ and $1.15 \mathrm{~g}$ $\mathrm{cm}^{-3}$ at the Oyster Landing and Bly Creek sites, respectively (Table 1). The sediment in these short

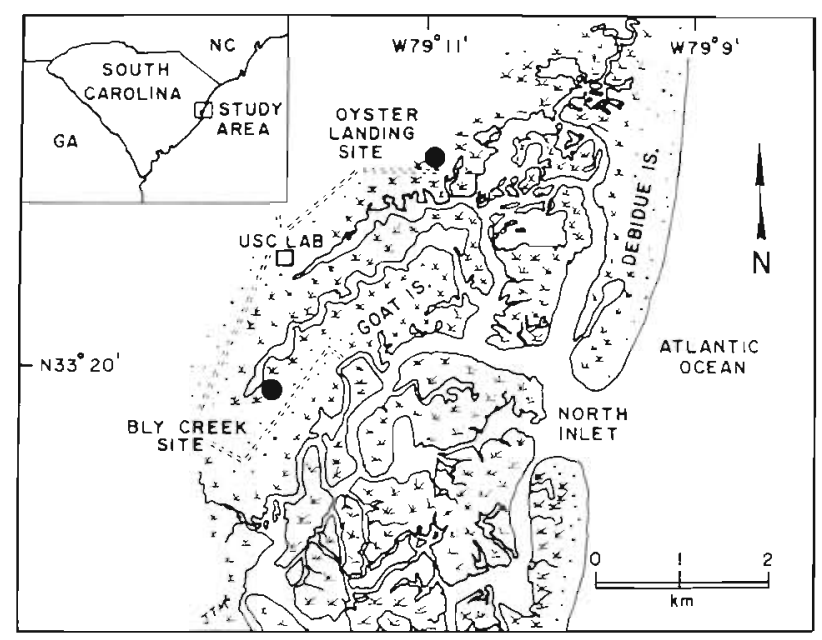

Fig. 1. Location of the study sites

Table 1. Mean standing biomass during early July and characteristics of the top $30 \mathrm{~cm}$ of sediment in short Spartina alterniflora marshes ( $\pm 1 \mathrm{SE})$ at the Oyster Landing and Bly Creek sites

\begin{tabular}{|c|c|c|}
\hline & \multicolumn{2}{|l|}{ Site } \\
\hline $\begin{array}{l}\text { Standing biomass } \\
\left.\text { (gdry wt } \mathrm{m}^{-2}\right) \quad \text { Live: } \\
\end{array}$ & $\begin{array}{l}144 \pm 23(4) \\
114 \pm 34(4)\end{array}$ & $\begin{array}{l}215 \pm 9(4) \\
141 \pm 5(4)\end{array}$ \\
\hline $\begin{array}{l}\text { Sediment characteristics } \\
\left.\text { Bulk dens. (g dry wt } \mathrm{cm}^{-3}\right) \text { : } \\
\text { Water content }\left(1 \mathrm{H}_{2} \mathrm{O} \mathrm{m}^{-3}\right) \text { : } \\
\text { Wt. loss after combustion } \\
\begin{array}{l}\text { \% of dry wt) } \quad 0-5 \mathrm{~cm} \text { : } \\
20-25 \mathrm{~cm} \text { : }\end{array}\end{array}$ & $\begin{array}{c}1.307 \pm 0.002(4) \\
512 \pm 26(4) \\
56 \pm 0.4(8) \\
1.75 \pm 01(8)\end{array}$ & $\begin{array}{l}1.153 \pm 0.038(3) \\
530 \pm 42(3) \\
8.3 \pm 30(5) \\
2.5 \pm 0.2(5)\end{array}$ \\
\hline - Sample size & & \\
\hline
\end{tabular}

S. alterniflora areas is sandy, although the Bly Creek sediments had about a 40 or $50 \%$ greater organic matter content than the Oyster Landing site (Table 1)

Water table and gas advection measurements. Water table depth was recorded by observing the water level in wells that were placed in the sediment. Wells were established by removing a $4.5 \mathrm{~cm}$ diameter sediment core to a depth of $35 \mathrm{~cm}$ and inserting a perforated PVC pipe. One well was installed in each of the short Spartina alterniflora areas at Oyster Landing and Bly Creek.

Duplicate gas advection measurements were made twice at the Oyster Landing site and once at the Bly Creek site. The measurements were made during daylight hours and lasted from the moment the tide left these areas until the sites were flooded. Measurements of gas advection and water table depth were made simultaneously at both sites.

The volume of gas advected into the sediment was measured by recording the displacement of an acid solution in a manometer as air was drawn into a core with a sealed headspace. At each site we placed duplicate $10 \mathrm{~cm}$ diameter, $30 \mathrm{~cm}$ length aluminum core tubes into the sediment between culms of Spartina alterniflora, capped them and connected their headspaces to manometers with Tygon tubing. We selected the position of each core tube so that the surface sediment inside was free of crab burrows or other holes. The caps were constructed of transparent plastic so that we could observe the sediment surface inside the core tube and confirm that there was no obvious difference in the elevation of sediment inside and outside the core at any time during the measurements. The caps were shielded from sunlight with aluminum foil to avoid temperature changes during the measurements. The manometers were made from $50 \mathrm{ml}$ glass burets, and each contained about $25 \mathrm{ml}$ of a $10 \%$ solution of $\mathrm{H}_{2} \mathrm{SO}_{4}$ for measuring the displacement of air. The relative positions of the buret and the Tygon tubing were frequently adjusted to equalize the levels of acid solution in the tubing and buret which maintained a headspace pressure of $1 \mathrm{~atm}$

Gas composition. Immediately after the tide flooded the Oyster Landing study site, gas bubbles expelled from the sediment were collected for analysis. We collected bubble samples that were expelled from the advection cores, but the majority of samples were of bubbles seen streaming from the sediment in the vicinity of the cores. Gas bubbles were collected in inverted glass beakers filled with tidal water over a period of about $15 \mathrm{~min}$ and then transferred in the field to $10 \mathrm{mI}$ glass syringes ( $\mathrm{B} \& \mathrm{D}$ Glaspak) equipped with 3-port valves (MEDEX). Concentrations of $\mathrm{CO}_{2}$ and $\mathrm{O}_{2}$ in these samples were measured within $24 \mathrm{~h}$ on a GC equipped with a $1 \mathrm{ml}$ sample loop and a thermal 
conductivity detector (Carle AGC), and the concentration of $\mathrm{CH}_{4}$ was measured on a GC equipped with a $1 \mathrm{ml}$ sample loop and a flame ionization detector (Varian 3700).

Water chemistry. Creek water from Oyster Landing and sediment pore water from the short Spartina alterniflora areas at the Oyster Landing and Bly Creek sites were analysed for total dissolved inorganic carbon (DIC). Each pore-water sample was obtained by drilling a fresh hole in the sediment to a depth of about 30 $\mathrm{cm}$ and allowing interstitial water to fill a $10 \mathrm{mI}$ vial inserted into the hole. When full, the vials were immediately capped with zero headspace, placed on ice, and analysed within $1 \mathrm{~h}$. The DIC extraction was made by injecting $0.5 \mathrm{ml}$ of pore water into a glass syringe containing $1 \mathrm{ml}$ of $10 \% \mathrm{H}_{2} \mathrm{SO}_{4}$ and $7 \mathrm{ml}$ of $\mathrm{N}_{2}$ gas. This mixture was shaken vigorously for $1 \mathrm{~min}$, and then the resulting mixture of $\mathrm{CO}_{2}$ and $\mathrm{N}_{2}$ gas was analysed on a GC with a thermal conductivity detector (Carle AGC).

Pore-water $\mathrm{pH}$ and chlorinity were also measured The $\mathrm{pH}$ measurements were made by inserting an electrode directly into the sediment to a depth of $5 \mathrm{~cm}$. The $\mathrm{pH}$ meter was calibrated in the field between each set of measurements. Chlorinity of the pore-water samples collected for DIC measurements was measured using a coulometric titrator (Haake Buchler).

Sediment cores. Sediment cores $(10 \mathrm{~cm}$ diameter, 30 $\mathrm{cm}$ length) were collected from the 2 sites for measurements of bulk density, organic matter, and water content. Eight cores were taken when the marsh was flooded and their wet weights compared to cores taken at low tide. Seven cores taken at low tide were dried at $60^{\circ} \mathrm{C}$ and weighed, and the volume of water contained in the cores calculated as the difference between their wet and dry weights. Subsamples of these cores, taken from $5 \mathrm{~cm}$ sections, were ashed at $600^{\circ} \mathrm{C}$ overnight for determinations of organic matter content.

Transpiration. In situ transpiration rates were measured on July 25 on single leaves of the tall form of Spartina alterniflora at Oyster Landing using a steady state porometer (LICOR LI1600). We made a conversion to transpiration rate per unit marsh surface area by measuring leaf areas (LICOR LI3000) and weights on 24 individual $S$. alterniflora plants (representing the full range of sizes encountered at our study sites), and by multiplying the resultant leaf area:weight ratio by the aboveground biomass of $S$. alterniflora at each site.

\section{RESULTS}

\section{Gas advection and water table depth}

Water table depths in areas of short Spartina alterniflora varied between 0 and $34 \mathrm{~cm}$ or more, depending on the location and date (Table 2). The maximum water table depth of $34 \mathrm{~cm}$ was observed on $11 \mathrm{July}$, the warmest day of our experiments: mean air temperature was $27.5^{\circ} \mathrm{C}$. The lowest mean temperature, $18.3^{\circ} \mathrm{C}$, corresponded to a water table depth of $0 \mathrm{~cm}$ on a cloudy day during the 9 September measurements.

The total volume of gas advected into the sediment during low tide exposure was as high as $4 \mathrm{~lm}^{-2}$, depending on the water table depth and site (Table 2). A representative time series of water table depths and a corresponding series of cumulative gas advection rates during a tidal cycle are shown in Fig. 2. In every instance where the water table fell, gas continued to be drawn into the sediment until the moment the site was flooded by the incoming tide.

Table 2. Maximum water table depths, mean volume of gas drawn into sediments during low tide (advection), pore-water chlorinity, and total dissolved inorganic carbon (DIC) concentrations in pore water $( \pm 1 \mathrm{SE}$ ). CW $=\mathrm{creek}$ water, OL $=\mathrm{OYster}$ Landing site, $\mathrm{BC}=$ Bly Creek site

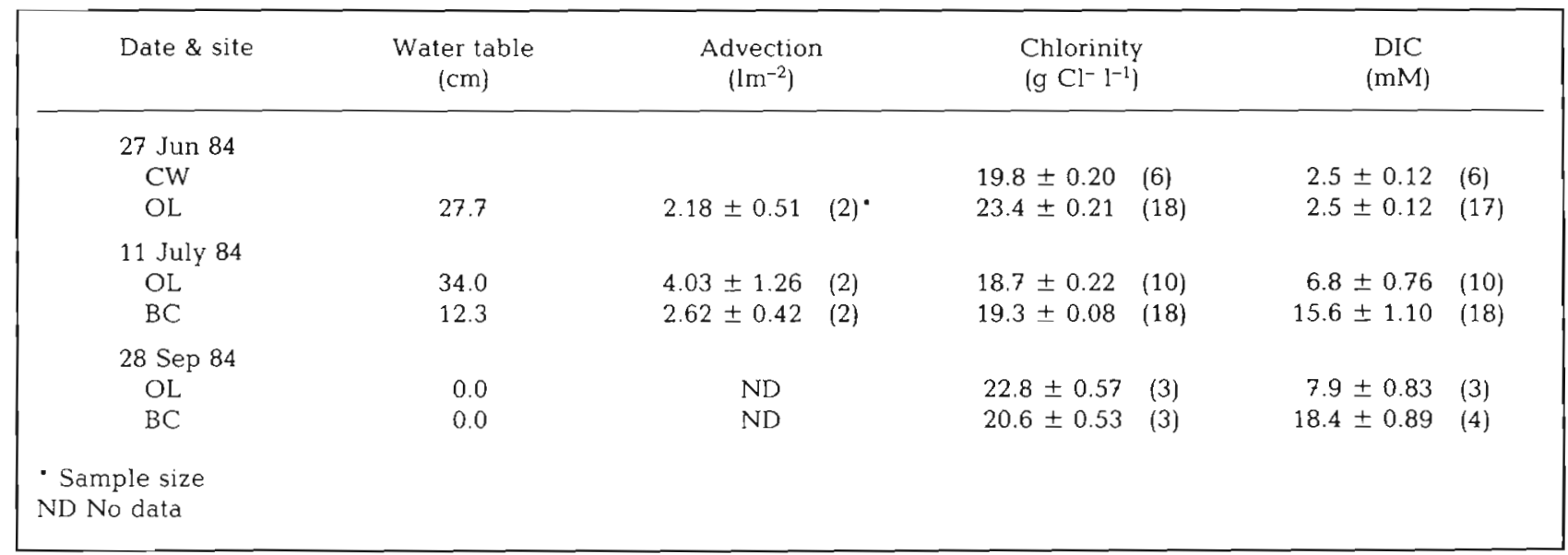


Fig. 2. Water table depth $(0-0)$ during low tide exposure and corresponding sediment of the short Spartina alterniflora Oyster Landing site on 11 July 1984. Gas advection measurements plotted here are derived from a single advection core and manometer cumulative advection of gas $(\bullet-\bullet)$ into

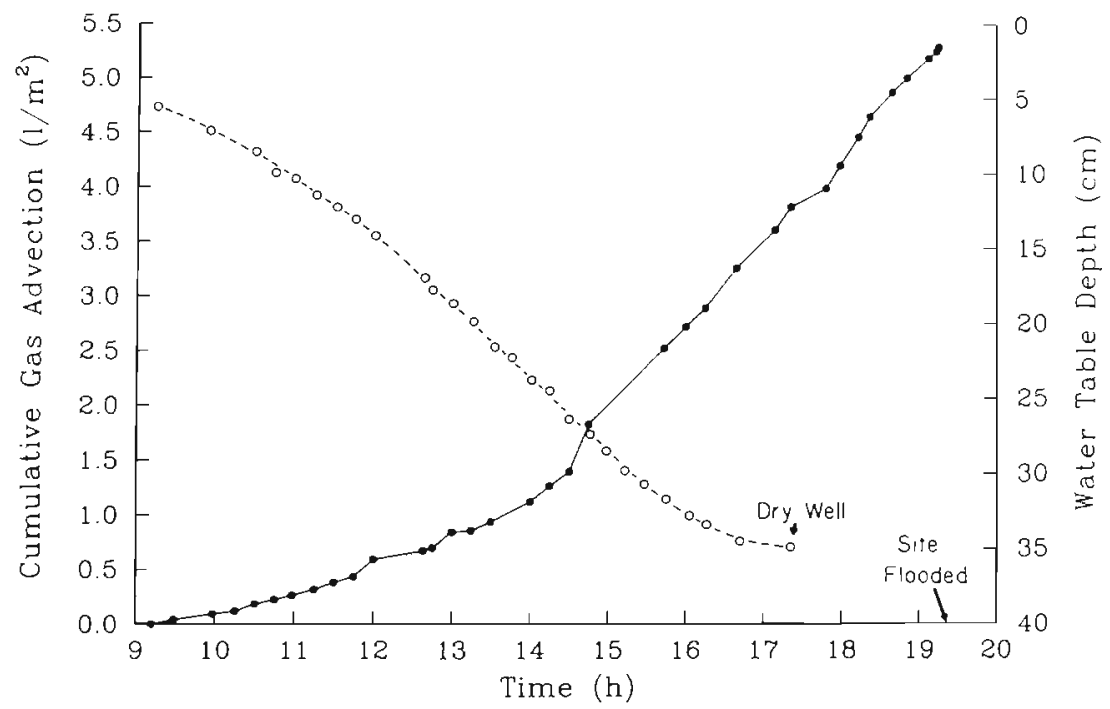

ple, at the Oyster Landing site during the 27 June experiment, a linear regression suggested that chlorinity increased by $4 \%$ over $8 \mathrm{~h}$ from $23.12 \%$ to $24.05 \%$ $(p<.18)$ (Fig. 3). During the same experiment, pore water collected along a creek bank at Oyster Landing in a zone dominated by the tall form of Spartina alterniflora also showed an increase in chlorinity from $20.44 \%$ to $21.22 \%$ or an increase of $3.5 \%$ over $5 \mathrm{~h}$ $(p<.15)$. Chlorinity of creek water did not show a trend and averaged $19.78 \pm 0.21 \%$ ( $\pm 1 \mathrm{SE}, \mathrm{n}=6)$.

\section{Transpiration}

Transpiration rates of individual Spartina alterniflora leaves averaged $7.5 \pm 0.98 \mu \mathrm{g} \mathrm{cm}^{-2} \mathrm{~s}^{-1}\left( \pm 1 \mathrm{SE}_{1}\right.$ $\mathrm{n}=7$ ) for the adaxial sides and $0.46 \pm 0.15 \mu \mathrm{g} \mathrm{cm}^{-2} \mathrm{~s}^{-1}$ $(n=3)$ for the abaxial sides. These measurements were made on leaves of tall $S$. alterniflora plants near midday when climatic conditions were nearly constant;

imum water table depth (Table 2) and volume-specific water content of sediments (Table 1) were used to calculate the total water content. Note that the \% of water lost from above the water table at Oyster Landing is lower despite its greater gas advection rate (Table 2), because its water table depth and, therefore, volume of water remaining above the water table were greater. These estimates of net water loss are consistent with an increase in chlorinity that was observed during the 27 June experiment, which is reported next (Fig. 3).

\section{Chlorinity}

Pore-water chlorinity varied among sites and between sampling dates (Table 2). Frequent measurements during low tide appear to show a trend toward increasing chlorinity between flood tides. For exam-

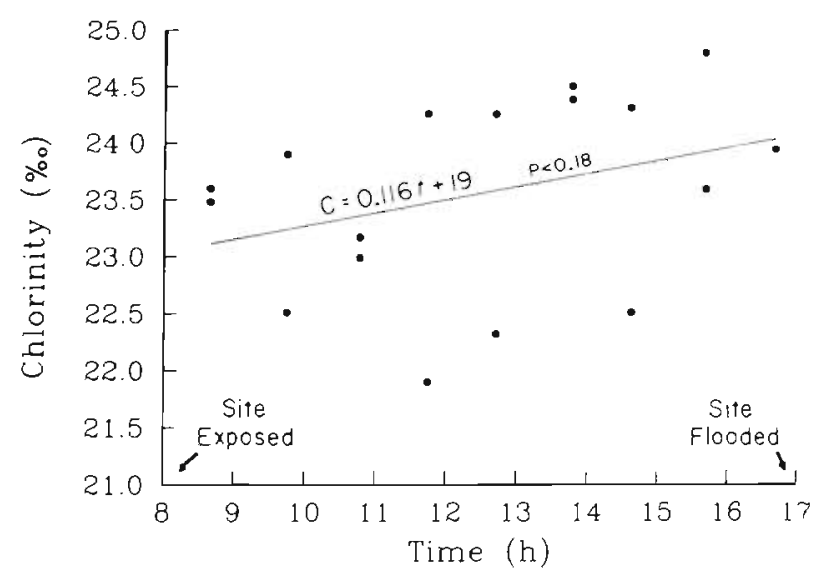

Fig. 3. Pore-water chlorinity at the short Spartina alterniflora Oyster Landing site during low tide exposure on 27 June 1984 
quantum flux density was $1760 \pm 197 \mu \mathrm{E} \mathrm{m} \mathrm{m}^{-2} \mathrm{~s}^{-1}$, relative humidity in the cuvette was $59.2 \%$, and leaf temperatures averaged $34.9 \pm 0.31^{\circ} \mathrm{C}$ or $0.8 \mathrm{C}^{\circ}$ higher than the cuvette temperature.

To extrapolate these rates to the marsh surface, we used linear regression analysis to obtain a highly significant relation between plant leaf area, A, (total of adaxial sides) and total plant dry weight, $\mathrm{W}$ :

$$
A\left(\mathrm{~cm}^{2}\right)=21.06 \mathrm{~W}(\mathrm{~g})+42.03\left(\mathrm{R}^{2}=.96, \mathrm{n}=24\right)(1)
$$

Substituting live standing biomass (Table 1) for $W$ in this equation gives total leaf areas of between 3075 and $4570 \mathrm{~cm}^{2} \mathrm{~m}^{-2}$ depending on the site, with corresponding transpiration rates of 88 to $132 \mathrm{ml} \mathrm{h}^{-1}$ per $\mathrm{m}^{2}$ of marsh surface. These transpiration rates could be considered to be maximum estimates because we used tall form Spartina alterniflora plants that probably had higher leaf area-specific rates than short form plants (Giurgevich \& Dunn 1979), and we assumed that the entire canopy was transpiring at a rate equal to leaves at the top of the canopy in direct sunlight at noon.

\section{Composition of expelled gas}

Analyses of the gas expelled from the sediment at high tide showed a significant depletion of $\mathrm{O}_{2}$ and enrichment of $\mathrm{CO}_{2}$ and $\mathrm{CH}_{4}$ (Table 3) relative to ambient air. The mean delta $\mathrm{O}_{2}$ was $-3.67 \pm 0.63 \mathrm{mM}$ $( \pm 1 \mathrm{SE}, \mathrm{n}=19)$; the mean delta $\mathrm{CO}_{2}$ was $1.67 \pm 0.02$ $\mathrm{mM}(\mathrm{n}=19)$; and, ignoring one anomalously high value from 11 July (Table 3), the mean delta $\mathrm{CH}_{4}$ was

Table 3. Mean concentrations ( $\pm 1 \mathrm{SE}$ ) of $\mathrm{CO}_{2}, \mathrm{O}_{2}$, and $\mathrm{CH}_{4}$ in gas advected from sediments at the Oyster Landing site

\begin{tabular}{|lccc|}
\hline \multicolumn{1}{|c}{ Date } & $\mathrm{CO}_{2}(\mathrm{mM})$ & $\mathrm{O}_{2}(\mathrm{mM})$ & $\mathrm{CH}_{4}(\mu \mathrm{M})$ \\
\hline 27 Jun 84 & $1.39 \pm 0.39(7)^{\circ}$ & $7.08 \pm 0.65(7)$ & $\mathrm{ND}$ \\
11 Jul 84 & $2.57 \pm 1.05(2)$ & $1.70 \pm 0.01(2)$ & $16.4 \pm 5.5(2)$ \\
25 Jul 84 & $1.65 \pm 0.20(10)$ & $5.42 \pm 0.49(10)$ & $1.19 \pm 0.29(9)$ \\
- Sample size & & \\
ND No data & & & \\
\end{tabular}

$1.6 \pm 0.5 \mu \mathrm{M}(n=10)$. Since the major fraction of the total gas volume was $\mathrm{N}_{2}$, it is likely that this gas was modified air that had been drawn into the sediment as opposed to gas generated entirely within the sediment. We found a significant $(p<.01)$ correlation between the delta $\mathrm{CO}_{2}$ (enrichment) and delta $\mathrm{O}_{2}$ (depletion) (Fig. 4), and a correlation between delta $\mathrm{CH}_{4}$ (enrichment) and delta $\mathrm{O}_{2}$ (depletion) was also significant $(p<.06)$. These correlations suggested that the variability in composition of gas advected from the sedi-

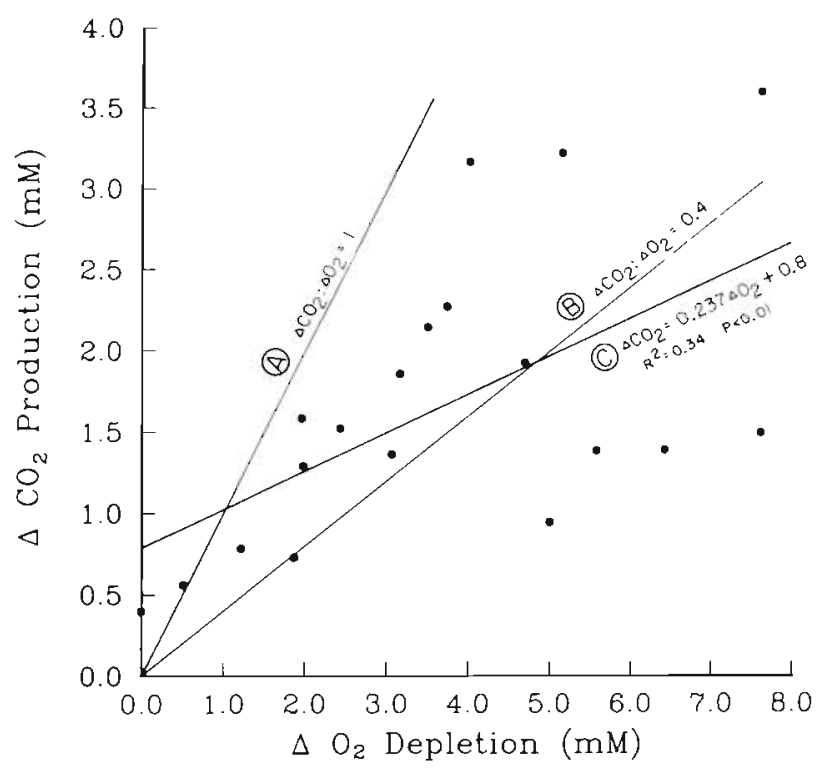

Fig. 4. Decrease in $\mathrm{O}_{2}$ concentration below ambient air versus increase in $\mathrm{CO}_{2}$ concentration above ambient air in gas bubbles advected from the sediment after tidal inundation at the short Spartina alterniflora Oyster Landing site. Samples were collected on 27 June, 11 July, and $25 \mathrm{July}, 1984$. Line A is the expected relation if $R Q=1$ and gas composition is influenced only by aerobic respiration. Line $B$ is a least-squares fit forced through the $(0,0)$ origin and is indicative of $R Q<1$. Line $C$ is a least-squares fit and is indicative of $R Q<1$ and a timevarying ratio of $\mathrm{CO}_{2}$ production: $\mathrm{O}_{2}$ consumption. See text for details

ment was probably related to the residence time of the gas in the sediment.

The relation between $\mathrm{CO}_{2}$ enrichment and $\mathrm{O}_{2}$ depletion can be used to make inferences about sediment respiratory processes. A 1:1 stoichiometry (line A in Fig. 4) would be observed if the changes in gas composition were determined completely by aerobic respiration. The slope (delta $\mathrm{CO}_{2} /$ delta $\mathrm{O}_{2}$ ) may be less than 1.0 due to the greater solubility of $\mathrm{CO}_{2}$ than $\mathrm{O}_{2}$ in water or sulfide oxidation by $\mathrm{O}_{2}$ (line $\mathrm{B}$ in Fig. 3). Gases only recently drawn into the sediment might have zero $\mathrm{CO}_{2}$ enrichment and zero $\mathrm{O}_{2}$ depletion, resulting in an intercept through the origin $(0,0)$. However, a positive intercept on the ordinate (line $\mathrm{C}$ in Fig. 4) could result if gases recently drawn into the sediment were enriched in $\mathrm{CO}_{2}$ that had accumulated in the porewater during the preceding high tide. The ratio of $\mathrm{CO}_{2}$ production: $\mathrm{O}_{2}$ consumption may also be variable over time, resulting in a non-zero origin because of a nonlinear relation between delta $\mathrm{CO}_{2}$ and delta $\mathrm{O}_{2}$. The exact relation between $\mathrm{O}_{2}$ depletion and $\mathrm{CO}_{2}$ production in these gas bubbles will depend on a number of factors including the age of the gas, rates and temporal patterns of sulfide oxidation, sulfate reduction, and aerobic respiration, and the relative rates of diffusion 
of gases within the sediment between the aqueous and gas phase.

\section{Pore-water chemistry}

Several possible explanations for the composition of gas expelled from the sediment are supported by observed changes in the chemistry of the pore water during low tide. For example, the consumption of $\mathrm{O}_{2}$ by sulfide oxidation, as described above, is consistent with a decrease in pore-water $\mathrm{pH}$ that was inversely related to water table depth during low tide (Fig. 5).

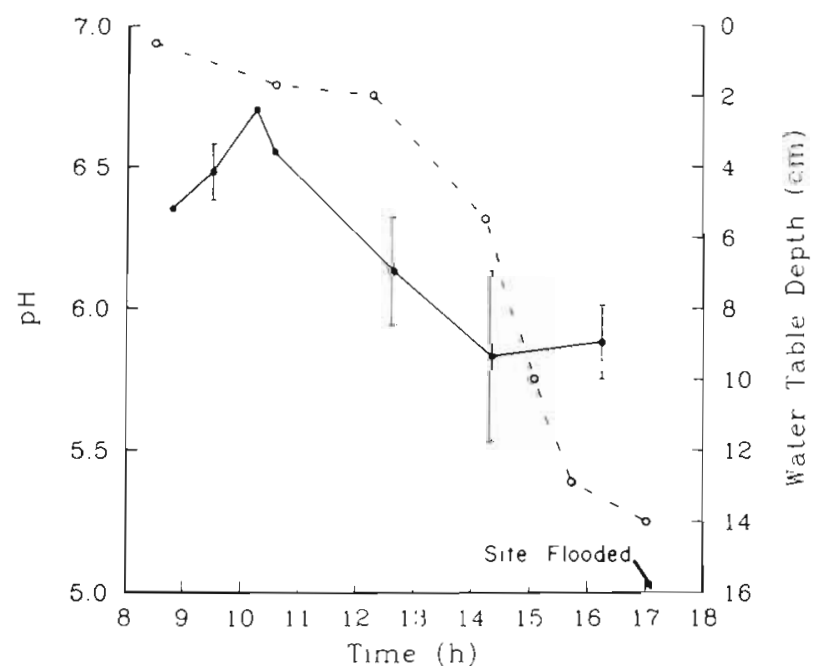

Fig. 5. Water table depth $\left(0^{-}-\right)$and mean pore water $\mathrm{pH}( \pm$ $1 \mathrm{SE}$ ) at $5 \mathrm{~cm}$ depth (-) during low tide exposure at the short Spartina alterniflora, Oyster Landing site on 23 August 1984

For $2 \mathrm{~h}$ after the tide had receded on 23 August, we first observed an increase in $\mathrm{pH}$ to a maximum of about 6.7 while the water table remained near the surface. Then, as the water table fell later in the day, $\mathrm{pH}$ decreased to a minimum of about 5.9 (Fig. 5). There was also a trend of increasing concentrations of dissolved inorganic carbon (DIC) at Oyster Landing between June and September (Table 2). This suggests that a portion of the $\mathrm{CO}_{2}$ produced in the sediment remains in a dissolved form. However, there was no significant trend in DIC concentration during any given experiment.

\section{DISCUSSION}

The consequences of gas advection could be considerable for many marsh biogeochemical processes. Its relative importance in the overall metabolism of $\mathrm{O}_{2}$ was seen during low tide exposure when consumption of $\mathrm{O}_{2}$ from gas advected into the sediment was $33 \%$ of
Table 4. Summary fluxes of $\mathrm{O}_{2}, \mathrm{CO}_{2}$ and $\mathrm{CH}_{4}$ in sediment at the short form Spartina alterniflora marsh at Oyster Landing during $10 \mathrm{~h}$ of low tide exposure in late summer. Negative quantities indicate net consumption, positive quantities net production. See text for details of the calculations

\begin{tabular}{lccc|} 
& $\begin{array}{c}\mathrm{O}_{2} \\
\left(\mathrm{mmol} \mathrm{m}^{-2}\right)\end{array}$ & $\begin{array}{c}\mathrm{CO}_{2} \\
\left(\mathrm{mmol} \mathrm{m}^{-2}\right)\end{array}$ & $\begin{array}{c}\mathrm{CH}_{4} \\
\left.(\mu \mathrm{mol} \mathrm{m})^{-2}\right)\end{array}$ \\
\hline By diffusion: & -22.0 & 51.4 & 228.4 \\
By advection: & -10.9 & 4.9 & 5.0 \\
Totals: & -32.9 & 56.3 & 233.4 \\
\hline
\end{tabular}

total $\mathrm{O}_{2}$ consumption (Table 4). The amount of $\mathrm{O}_{2}$ consumption from gas advected into the sediment (consumption $=$ volume of gas drawn into sediment $\times$ [concentration in - concentration out]) was 10.9 mmol $\mathrm{m}^{-2}$ tide $^{-1}$ (Table 4 ). We made this calculation using a mean gas advection rate of $2.94 \mathrm{l} \mathrm{m}^{-2}$ tide $^{-1}$ (see Table 2) and a mean $\mathrm{O}_{2}$ concentration of gas advected from sediment of $5.66 \mathrm{mM}$ (see Table 3 ). This compares to an $\mathrm{O}_{2}$ consumption by the sediment from diffusion alone of $22.0 \mathrm{mmol} \mathrm{m} \mathrm{m}^{-2}$ tide $^{-1}$ (Table 4). This latter rate was derived by measuring the rate of $\mathrm{O}_{2}$ depletion $\left(2.2 \pm 0.4 \mathrm{mmol} \mathrm{m} \mathrm{m}^{-2} \mathrm{~h}^{-1}, \pm 1 \mathrm{SE}, \mathrm{n}=13\right)$ from the headspace above sediment cores incubated in the laboratory for periods of 14 to $92 \mathrm{~h}$ and assuming that the exposure time during low tide was $10 \mathrm{~h}$. Thus, in situ measurements that rely entirely on diffusive gas exchanges may significantly underestimate $\mathrm{O}_{2}$ consumption.

The relative rates of gas diffusion and advection across the sediment surface depend on a number of factors. These include the net water loss and compressibility of the sediment, the residence time of advected gas in the sediment, the solubility of the gas, and the ratio of marsh surface area to the surface area of airfilled pore spaces within the sediment. For $\mathrm{CO}_{2}$, advective fluxes were small in comparison with diffusive fluxes. The mean $\mathrm{CO}_{2}$ concentration from all samples of gas expelled from sediments $(1.67 \pm 0.21 \mathrm{mM}, \pm 1$ $\mathrm{SE}, \mathrm{n}=19)$ and the mean gas advection rate $\left(2.94 \mathrm{l} \mathrm{m}^{-2}\right)$ give a rate of $\mathrm{CO}_{2}$ advection of $4.92 \mathrm{mmol} \mathrm{CO}_{2} \mathrm{~m}^{-2}$ tide ${ }^{-1}$. In contrast, the in situ rate of $\mathrm{CO}_{2}$ diffusion from the sediment surface in late July, obtained by measuring the rate of accumulation of $\mathrm{CO}_{2}$ in the headspace of core tubes placed into the sediment, was $5.14 \pm 1.05$ mmol $\mathrm{CO}_{2} \mathrm{~m}^{-2} \mathrm{~h}^{-1}( \pm 1 \mathrm{SE}, \mathrm{n}=8)$ (Morris \& Whiting in press). Thus, the rate of $\mathrm{CO}_{2}$ diffusion from the sediment during $10 \mathrm{~h}$ of low tide exposure was $51.4 \mathrm{mmol}$ $\mathrm{m}^{-2}$ or 10 times greater than the advection rate (Table 4).

Methanogenesis was minor in comparison with sulfate reduction and/or aerobic respiration, as indicated by the relatively small $\mathrm{CH}_{4}$ losses from sediment; and, 
like $\mathrm{CO}_{2}$, diffusive losses of $\mathrm{CH}_{4}$ exceeded advective losses (Table 4). The mean gas advection rate (2.94 1 $\mathrm{m}^{-2}$ ) and mean $\mathrm{CH}_{4}$ concentration in samples of expelled gas $(1.69 \mu \mathrm{M} \pm 0.53, \pm 1 \mathrm{SE}, \mathrm{n}=10)$ indicate that the $\mathrm{CH}_{4}$ advective loss was $5.0 \mu \mathrm{mol} \mathrm{m}{ }^{-2}$ tide $^{-1}$. In contrast, in situ measurements of $\mathrm{CH}_{4}$ accumulation in the headspace of cores during July gave a mean rate of $\mathrm{CH}_{4}$ diffusion from the sediment surface of $22.8 \pm 6.5$ $\mu \mathrm{mol} \mathrm{m} \mathrm{m}^{-2} \mathrm{~h}^{-1}( \pm 1 \mathrm{SE}, \mathrm{n}=6)$. Thus, during $10 \mathrm{~h}$ of low tide exposure, diffusive $\mathrm{CH}_{4}$ fluxes were $228 \mu \mathrm{mol} \mathrm{m}{ }^{-2}$ tide $^{-1}$ or 46 times greater than advective fluxes (Table 4).

In gas expelled from the sediment at high tide, the ratio of $\mathrm{CO}_{2}$ evolved to $\mathrm{O}_{2}$ consumed was less than the 1:1 stochiometry expected of aerobic respiration (Fig. 4), which appears to result in part because of sulfide oxidation. This is consistent with the decrease in $\mathrm{pH}$ that was observed during the water table draw-down (Fig. 5). Sulfide oxidation has been postulated to occur seasonally (Howarth \& Teal 1979, Giblin \& Howarth 1984). Our data suggests that it may also be important on shorter time scales and that $\mathrm{O}_{2}$ is probably drawn into the sediment to the depth of the water table.

The ratio of $\mathrm{CO}_{2}$ evolved to $\mathrm{O}_{2}$ consumed in expelled gas would also be less than the 1:1 stoichiometry expected of aerobic respiration if some of the $\mathrm{CO}_{2}$ produced remained in the water as DIC. This is a likely possibility because the solubility of $\mathrm{CO}_{2}$ is so great. In the Great Sippewissett salt marsh, Howes et al. (1985) found seasonal differences in the concentration of DIC in the pore water that were correlated with the rate of sediment $\mathrm{CO}_{2}$ production. We were unable to detect a change in concentration of DIC in the pore water during any single experiment, but we did see an increase in the DIC concentration in pore water at Oyster Landing between June 27 and September 28 (Table 2)

The volume of gas drawn into the sediment will likely vary among marsh sites and temporally, since advection depends on the compressibility of sediments, drainage, tidal stage, and evapotranspiration rate. Transpiration rates at the Oyster Landing site were potentially as high as $88 \mathrm{ml} \mathrm{m}^{-2} \mathrm{~h}^{-1}$ on a day when water table depth fell to $33 \mathrm{~cm}$ and net water loss from sediment was probably about $4 \mathrm{l} \mathrm{m}^{-2}$ over $10 \mathrm{~h}$. Thus, transpiration alone accounted for perhaps $22 \%$ of net water loss from sediment. Evaporation from the sediment surface may have accounted for the remaining water loss, or there may be an additional loss resulting from subsurface drainage toward the tidal creek. However, since the water table remained at the surface on cool cloudy days, this suggests that drainage is of minor importance at the locations of our study sites. Note that our estimate of sediment water loss, derived from gas advection rates, is a net rate. The total water loss could be greater, because ground water movements may replace some water loss by evapotranspiration (Hemond \& Fifield 1982). Gas advection would be reduced to the extent that subsurface water inputs supplemented the total water loss. However, we did not see a decrease in chlorinity (Fig. 3) from fresh water intrusion, although this does not eliminate the possibility of inputs of saline water from higher elevations in the marsh.

The advection of gas in marsh sediments could have an impact on Spartina alterniflora production; as sediments become more oxidized the uptake of nutrients would be enhanced (Morris 1984, Morris \& Dacey 1984) and production should increase. S. alterniflora growth has been correlated to water table level at low tide in a North Carolina marsh (Mendelssohn \& Seneca 1980). In the marshes where our measurements were made maximum water table depth at low tide occurs along creek banks (Gardner 1973) where S. alterniflora biomass is greatest and where drainage is presumably greater. There could also be a positive feedback between $S$. alterniflora growth and sediment oxidation (Howes et al. 1981), since sediment oxidation is a function of evapotranspiration rate (Dacey \& Howes 1984). In intertidal sediments, flood tides raise the water table and replace the air in the sediment, while evapotranspiration lowers the water table during the low tide and draws air into the sediment. These processes result in a turnover of air and water in the sediment, and it is possible that this property might enhance the productivity of tidal wetland ecosystems in general.

Acknowledgements. This work was supported by grants DEB8214795 and BSR-8317407 from the National Science Foundation.

\section{LITERATURE CITED}

Broome, S. W., Woodhouse, Jr., W W., Seneca, E. D. (1975). The relationship of mineral nutrients to growth of Spartina alterniflora in North Carolina. II. The effects of N, P, and Fe fertilizers. Soil Sci. Soc. Am. Proc. 39: 301-307

Chalmers, A. G. (1982). Soil dynamics and the productivity of Spartina alterniflora. In: Kennedy, V. S. (ed.) Estuarine comparisons. Academic Press, New York, p. 231-242

Dacey, J. W. H., Howes, B. L. (1984). Water uptake by roots controls water table movement and sediment oxidation in short Spartina marsh. Science 224: 487-489

Delaune, R. D., Smith, C. J., Patrick, Jr., W. H. (1983). Relationship of marsh elevation, redox potential, and sulfide to Spartina alterniflora productivity. Soil Sci. Am. J. 47: 930-935

Gallagher, J. L. (1975). Effect of an ammonium nitrate pulse on the growth and elemental composition of natural stands of Spartina alterniflora and Juncus roemerianus. Am. J. Bot. 62: 644-648

Gardner, L. R. (1973). The effect of hydrologic factors on the 
pore water chemistry of intertidal marsh sediments. Southeast Geol. 15: 17-28

Giblin, A. E., Howarth, R. W (1984). Porewater evidence for a dynamic sedimentary iron cycle in salt marshes. Limnol Oceanogr. 29: 47-63

Giurgevich, J. R., Dunn, E. L. (1979). Seasonal patterns of $\mathrm{CO}_{2}$ and water vapor exchange of the tall and short height forms of Spartına alterniflora Loisel. in a Georgia salt marsh. Oecologia (Berl.) 43: 139-156

Hemond, H. F., Fifield, J. L. (1982). Subsurface flow in salt marsh peat: a model and field study. Limnol. Oceanogr. 27: $126-136$

Hemond, H. F., Nuttle, W. K., Burke, R. W., Stolzenback, K. D. (1984). Surface infiltration in salt marshes: theory, measurement, and biogeochemical implications. Water Resour. Res. 20: 591-600

Howarth, R. W (1979). Pyrite: its rapid formation in a salt marsh and its importance to ecosystem metabolism. Science 203: 49-51

Howarth, R. W., Teal, J. M. (1979). Sulfate reduction in a New England salt marsh. Limnol. Oceanogr 24: 999-1013

Howes, B. L., Dacey, J. W. H., Teal, J. M. (1985). Annual carbon mineralization and below-ground production of Spartina alterniflora in a New England salt marsh. Ecology 66: 595-605

Howes, B. L., Howarth, R. W., Teal, J. M., Valiela, I. (1981). Oxidation-reduction potentials in a salt marsh: spatial patterns and interactions with primary production. Limnol. Oceanogr 26: 350-360

King, G. M., Klug, M. J., Wiegert, R. G., Chalmers, A. G. (1982). Relation of soil water movement and sulfide concentration to Spartina alterniflora production in a Georgia salt marsh. Science 218: 61-63
Mendelssohn, I. A., McKee, K. L., Patrick, Jr., W H. (1981). Oxygen deficiency in Spartina alterniflora roots: metabolic adaptation to anoxia. Science 214: $439-441$

Mendelssohn. I. A., Seneca, E. D. (1980). The influence of soil drainage on the growth of salt marsh cordgrass Spartina alterniflora in North Carolina. Estuar. coast. mar. Sci. 11 $27-40$

Morris, J. T (1984). Effects of oxygen and salinity on ammonium uptake by Spartina alterniflora Loisel. and Spartina patens (Aiton) Muhl. J. exp. mar. Biol. Ecol. 78: $87-98$

Morris, J. T., Dacey, J. W. H. (1984). Effects of $\mathrm{O}_{2}$ on ammonium uptake and root respiration by Spartina alterniflora. Am. J. Bot. 71: 979-985

Morris, J. T., Whiting, G. J. (1986). Emission of gaseous $\mathrm{CO}_{2}$ from salt marsh sediments and its relation to other carbon losses. Estuaries (in press)

Patrick, Jr., W. H., DeLaune, R. D. (1976). Nitrogen and phosphorus utilization by Spartina alterniflora in a salt marsh in Barataria Bay, Louisiana. Estuar. coast. mar. Sci. 4: 59-64

Sullivan, M. J., Daiber, F. C. (1974). Response in production of cordgrass, Spartina alterniflora, to inorganic nitrogen and phosphorus fertilzer. Chesapeake Sci. 15: 121-123

Valiela, I., Teal, J. M. (1974). Nutrient limitation in salt marsh vegetation. In: Reimold, R. J, Queen, W. H. (ed.) Ecology of halophytes. Academic Press, New York, p. 547-563

Wiegert, R. G., Chalmers, A. C., Randerson, P. F. (1983). Productivity gradients in salt marshes: the response of Spartina alterniflora to experimentally manipulated soil water movement. Oikos 41:1-6 